\title{
Should the Model Penal Code's Mens Rea Provisions Be Amended?
}

\author{
Kenneth W. Simons*
}

\section{INTRODUCTION}

Do the Model Penal Code's (MPC) provisions on mental states need revision? The question might seem preposterous. After all, many believe that these provisions count as the MPC's greatest achievement: they clarify and simplify mental state categories, and replace an undifferentiated focus on the mens rea of an offense with a more careful focus on the mens rea for each element of an offense.

The drafters of the MPC indeed have much to be proud of here. Prior to the MPC, the prevailing mental state categories included general intent and specific intent, malice aforethought, and other concepts that were just as confusing. And in many states, these confusing and infinitely manipulable old concepts are still with us. Consider one well-known recent case. In Commonwealth v. Woodward, a nanny was charged with murder for allegedly violently shaking a baby and slamming him against the floor, resulting in his death. The judge instructed the jury that, to decide whether she acted with "malice," they should determine "whether, under the circumstances known to Defendant, a reasonable person would have known that her intentional act created a substantial risk of death to [the victim]." Notice that this sounds like a narrow criterion, insofar as it requires proof of the most culpable mens rea criteria- -intentionally" and "known." Yet the most important part of the criterion ("a reasonable person would have known") requires only ordinary negligence. And, taken literally, the criterion is quite easy to satisfy: it would permit a murder conviction for a beginning driver who "intentionally" switches lanes, "knowing" that he is on a busy highway, but negligently fails to check his blind spot and causes a fatal collision.

Nevertheless, in this essay I will suggest that the MPC did lose something in departing from more traditional mens rea criteria. Furthermore, the MPC approach creates new problems, some rather significant. So a fine-tuning of the MPC approach, at least, would be worthwhile.

- Professor of Law and M. L. Sykes Scholar, Boston University School of Law. I thank Eric Blumenson, Stan Fisher and Gerry Leonard for their perceptive comments and Kara Rohe for her valuable research assistance.

This essay is a significantly expanded version of remarks presented at the AALS Criminal Justice Section Panel on the Future of the Model Penal Code, January 2003.

Commonwealth v. Woodward, 7 Mass. 449 (1997), affd and remanded by 694 N.E.2d 1277 (Mass. 1998). 
To be sure, the problems with the MPC's culpability provisions are not so severe that they alone would justify the enormous effort of developing a revised Model Penal Code Second. But if such an effort is undertaken, serious thought should be given to the matters identified in this essay.

The essay proceeds as follows. First, it emphasizes that the MPC approach to mens rea was a tremendous advance. The MPC carefully defines a limited number of mens rea terms, firmly establishes element analysis in place of offense analysis, and recognizes that the doctrine of mistake is part and parcel of the basic analysis of mens rea.

However, a revised Code could improve the drafting of the mens rea provisions in a number of respects. Moreover, more fundamental questions arise with the central concept of recklessness. A reckless actor is one who must be aware of a "substantial and unjustifiable" risk; are these independent or interdependent requirements? What type or degree of consciousness is required? Of what, precisely, must the actor be aware? Does a strict "consciousness" requirement undermine the rule that ignorance of law is no excuse? And should consciousness extend to "latent" knowledge that the actor could call up if he were to consider the matter even for a moment?

Furthermore, does the MPC hierarchy always work? Is knowledge really always worse than recklessness? Is recklessness always worse than negligence? Should culpable indifference or a similar mental state be added to the hierarchy? Are the MPC categories too cognitive, or too descriptive, or too rigid? Finally, the conclusion examines some theoretical and pragmatic implications of the analysis.

\section{THE MOdEL PENAL CODE'S ACCOMPLISHMENTS}

Let me start with a reminder of what the MPC did accomplish in this area. The MPC's approach to mental states or culpability terms was a tremendous advance, in four important ways:

- The MPC limits the number of mens rea terms to four-purpose, knowledge, recklessness, and negligence-plus strict liability. ${ }^{2}$

- The MPC's definitions of mens rea terms are much clearer than are traditional definitions, which often are not spelled out in the governing legislation at all. In particular, the MPC's definitions of recklessness and negligence are not nearly as vague as the criteria that many traditional jurisdictions employ. ${ }^{3}$

2 However, the MPC also recognizes the more traditional mens rea category, "extreme indifference," as one type of murder. The drafters' decision to depart from the new, simplified hierarchy, especially in the context of the most serious crime, murder, demonstrates a genuine and significant difficulty with that hierarchy. See infra notes 55-56.

3 See MOdel Penal CODE $\$ 2.02 \mathrm{cmt}$. at 238 (1985) [hereinafter MPC Commentaries] (the new recklessness definition avoids "essentially epithetical" traditional language). 
- The MPC firmly establishes the idea of element analysis in place of "offense analysis." A single crime can employ different mens rea criteria for different elements (and the relevant elements for which mens rea can vary include justifications such as self-defense as well as elements of the prima facie case).

- The MPC recognizes that mistake is not a separate doctrine, but part and parcel of the basic analysis of mens rea. Figuring out which mistakes and which cases of ignorance will result in nonliability is just a question of "logical relevance": Does the mistake or ignorance negate the required mens rea or not? ${ }^{4}$

Other contributions of the MPC are also noteworthy: clarifying the subjective/objective distinction, at least to some extent; ${ }^{5}$ adding some helpful interpretive principles; ${ }^{6}$ and attempting to clarify when mistake or ignorance of law is a defense.

Nevertheless, the Code's provisions do create some problems. A first group of problems could be described as internal and more technical-that is, as problems with the implementation of the general "element analysis" approach. A second group of problems is more fundamental. What does the critical mental state of "recklessness" really require? What type of "consciousness" is required, and precisely what facts must the actor advert to? Is the Code's purpose/knowledge/recklessness/negligence hierarchy complete, or is it missing something? And are "higher" mental states within the hierarchy always more culpable than "lower" mental states?

See Model Penal Code § 2.04(1) (1985); MPC Commentaries, supra note 3, at 269.

5 Purpose and knowledge are entirely on the subjective side, focusing completely on the individual actor's state of mind; negligence is almost entirely on the objective side, focusing on the actor's failure to be aware of a risk and gross deviation from reasonable care; and recklessness is somewhere in between, with a purely subjective focus on consciousness of risk but also the same objective "gross deviation" standard that the negligence test provides.

6 If a statute contains no explicit mens rea terms, the default mens rea for all material elements is recklessness. If the statute contains a mens rea term that clearly applies to several elements-for example, if the adverb "purposely" or "knowingly" precedes "causes the death of a police officer" or "receives stolen property"- then that initial term "travels" through the several elements, applying to all. Model Penal CODE $\$ 2.02(4)$ (1985). I dub this the "travel" rule. Markus Dubber calls it "onefor-all." Markus D. Dubber, Criminal Law: Model Penal Code 54 (2002).

7 See Model Penal CODE $\S 2.04(1)$ (1985) (treating certain mistakes of law as mistakes of fact); MODEL PENAL CODE $\S 2.04(3)$ (1985) (requiring no culpability as to most mistakes of governing law, with limited exceptions). This attempt does not quite succeed, however. See infra notes $17-21$ and accompanying text. 


\section{INTERNAL PROBLEMS}

The Code's element analysis is a bit too complicated, and sometimes imprecise. Here are a number of queries and suggestions for improvements.

\section{A. Clarify how to distinguish result, circumstance, and conduct elements from one another}

The distinction between these three types of offense elements matters for the definitions of purpose and knowledge, for characterizing the required mens rea of inchoate crimes such as attempt, and in some other situations. Yet the MPC never explicitly differentiates them. Paul Robinson, among others, has offered some plausible criteria. ${ }^{8}$

\section{B. Perhaps simplify the definitions of knowledge and purpose}

"Knowledge" could be given the same meaning, whether it applies to a circumstance or result element;" and "purpose" could be simplified in a similar manner. (An incidental benefit of this change is that the distinction between circumstance and result would less often matter.)

Thus, with respect to knowledge, is it really worth distinguishing a belief that a result is "practically certain" from a belief that a circumstance is "highly probable"?" Why not use "practically certain," "highly probable" or a similar term in both instances? And, with respect to purpose, would it not suffice to define "purpose" with respect to results, and then simply provide that when "purposely" applies to a circumstance element, it means "knowledge"? ${ }^{10}$

8 See Paul H. Robinson \& Jane A. Grall, Element Analysis in Defining Criminal Liability: The Model Penal Code and Beyond, 35 STAN. L. REV. 681, 719-24 (1983); Paul H. Robinson, Rethinking Federal Criminal Law: Reforming the Federal Criminal Code: A Top Ten List, 1 Buff. Crim. L. Rev. 225, 235-39 (1997); see also JoshuA DresSler, UNDERSTANDING CRIMINAL LAW 111-12 (3d ed. 2001); Kenneth W. Simons, Rethinking Mental States, 72 B.U. L. REV. 463, 535 n.250 (1992) (suggesting a slight variation on Robinson's approach).

9 See Model Penal Code $\S \S 2.02(2)(\mathrm{b})(\mathrm{ii}), 2.02(7)$ (1985). Indeed, the Code's definition of knowledge as to a circumstance must be derived from two sources: the basic definition, "aware that such circumstances exist," in $\S 2.02(2)(b)(i)$; and "aware of a high probability of its existence," in $\S 2.02(7)$. The latter phrase presumably controls the former, since it is a weaker requirement. To be sure, the "high probability" language is followed by a qualifying clause, but this clause creates its own set of problems. See infra Part III(F).

10 This approach would differ from the Code's mainly in dropping the Code's provision that "purpose" as to a circumstance is satisfied either by belief or by "hope" that the circumstance exists. But I have not found any reported case relying on the "hope" provision alone, and it is also doubtful whether a bare desire that an illicit fact exist is a proper basis of criminal punishment. Read literally, the Code's "hope" provision allows conviction of a defendant who merely desires that unlawful circumstances exist, even if he is confident that it does not exist and would not act differently even if he thought it did. See Kenneth W. Simons, Does Punishment for "Culpable Indifference" Simply 
It also might be worthwhile to specify what "high probability" and "practical certainty" mean. How high a likelihood? Is greater than $50 \%$ enough for "high probability"?" high enough probability here? Even if we are uncomfortable employing a precise number, greater clarity would be valuable. ${ }^{12}$ (Some states that have adopted versions of the MPC definitions of knowledge have used different language, such as "reasonably certain," ${ }^{13}$ but these versions, too, are often imprecise. ${ }^{14}$ )

\section{Perhaps eliminate the category of "mens rea as to conduct"}

It is normally unduly confusing, and not analytically helpful, to retain this category. As Paul Robinson has argued, the typical case in which we are worried about culpability as to one's own conduct (as opposed to culpability as to the result of one's conduct, or as to a circumstance) is where we have doubts about the voluntariness of the conduct. ${ }^{15}$ The voluntary act requirement is usually sufficient to address this difficulty. For example, if burglary requires "entering" the dwelling of another, it is rarely helpful to ask whether the actor is "negligent," "reckless," or "knowing" as to whether he is "entering" the building. If someone throws him into

Punish for "Bad Character"? Examining the Requisite Connection between Mens Rea and Actus Reus, 6 Buff. CRIM. L. ReV. 219, 239 (2002).

1 The Commentaries contain a hint that a "high" probability is meant to be considerably more than a 50\% probability. They describe as "more expansive" than the MPC position the definition in Ohio's code that knowledge is satisfied when the result or circumstance is "probable." MPC Commentaries, supra note 3, at 248 n.43.

12 See Alan C. Michaels, Acceptance: The Missing Mental State, 71 S. CAL. L. REV. 953, 983 n. 105 (1998); Ira P. Robbins, The Ostrich Instruction: Deliberate Ignorance as a Criminal Mens Rea, 81 J. CRIM. L. \& CRIMINOLOGY. 191, 223-24 (1990). Insofar as jurors have difficulty understanding percentages, an instruction could include an equivalent paraphrase.

13 TEX. Penal CODE § 6.03(b) (1994) (defining knowledge as to a result element). Moreover, Washington defines knowledge as including not only awareness, but also possession of "information which would lead a reasonable man in the same situation to believe" that an offense element exists. WASH. REV. CODE $\S 9 A .08 .010(1)(b)(i i)$ (2000). This definition makes a certain type of negligence sufficient for "knowledge"!

14 However, Ohio defines "knowledge" as awareness that one is "probably" causing a result or that a circumstance "probably" exists. Apparently this means simply "more likely than not"; thus, it is a precise criterion. 1973 Ohio Legis. Serv. (Banks-Baldwin). On the other hand, Ohio also defines "reckless" as (among other things) a known risk that the result or circumstance is "likely." Strangely enough, "likely" seems to mean, not "more likely than not," but only that there is good reason for expectation or belief. Id.

15 See Robinson \& Grall, supra note 8, at 721-23; PAUL H. Robinson, CRIMINAL LAW $\$ 4.2$ (1997); David M. Treiman, Recklessness and the Model Penal Code, 9 AM. J. CRIM. L. 281, 310-16 (1981); see also Michael S. Moore, Actus Reus, in 1 ENCYCLOPEDIA OF CRIME \& JUSTICE 15, 22-24 (Joshua Dressler ed., 2d ed. 2002). 
the building, he lacks any culpable state of mind as to the conduct element "entering," but he also hasn't acted voluntarily. ${ }^{16}$

D. Clarify the fact/law distinction, and especially the distinction between two types of mistakes of law-mistakes of governing law and mistakes of. legal element - that the MPC treats differently

Consider a crime such as "knowingly receiving stolen property." Is the defendant guilty if he makes a mistake about whether the property is, in law as well as fact, "stolen"? For example, suppose he realizes that the person from whom he received the property took it from someone's garbage bin on private property, and he believes incorrectly that such property does not count as "stolen" because he believes, again incorrectly, that under these circumstances, the property no longer belongs to the original owner.

If this type of mistake is considered a mistake of governing law-namely, a mistake "as to whether conduct constitutes an offense or as to meaning . . . or application of the law determining the elements of an offense" rea will be required (with very rare exceptions). But if it is considered a mistake of legal element, under $\S 2.04(1)$, then it would be treated like mistake of fact, and could exculpate if the mistake demonstrates that the actor lacks the culpability required for the crime. ${ }^{18}$

When the mistake of legal element is a mistake as to a legal category defined elsewhere in the jurisdiction's law-especially its civil law-then the "legal element" label fits most easily. (Suppose "stolen property" is defined in the commercial code of the jurisdiction.) But what if the definition comes from elsewhere in the state's criminal code? ${ }^{19}$ Or even from judicial opinions

16 Sometimes, the characteristics of one's conduct are appropriately treated as a circumstance element, to which any of the MPC's mens rea terms can apply. For example, if it is a crime to insult another in a manner likely to provoke violence, then "[u]nder a narrow view of the conduct element, the required conduct is the simple act of speaking. The conduct's characteristics-its insulting character, its likelihood of promoting a violent response-would be treated as circumstance or result elements." RoBINSON, supra note 15, at 235 (1997); Robinson, supra note 8, at 238.

17 Model Penal Code $\S 2.02(9)$ (1985).

18 See MODEL PENAL CODE $\S 2.04(1)$ (a) (1985): "Ignorance or mistake as to a matter of fact or law is a defense if . . . the ignorance or mistake negatives the purpose, knowledge, belief, recklessness or negligence required to establish a material element of the offense." (emphasis added). The Commentaries use the example of a (traditional) rape statute in which the actor mistakenly believes that a woman is his wife. If his mistake concerns eligibility to marry, then, the Commentaries conclude, it does not matter whether this mistake is considered one of law or fact. See MPC Commentaries, supra note 3, at 270; see also id. at 250 (suggesting that the "ignorance of law is no defense" principle is "greatly overstated" because the circumstances made material by the definition of an offense frequently include a legal element).

19 See, e.g., People v. Marrero, 507 N.E.2d 1068, 1068 (N.Y. 1987); cf. People v. Bray, 124 .Cal. Rptr. 913, 913 (Cal. Ct. App. 1975) (deriving the relevant definition of "felony" from the criminal law of another state). 
interpreting the statute in question? (For example, the relevant definition of "stolen" might come entirely from interpretations of the criminal theft statutes themselves.) In any case, even in the "easier" case where the definition derives from the jurisdiction's civil law, why should this be treated differently from a case where the definition comes from the criminal code itself? And why should it be treated differently from a case where the defendant does not know that "knowing receipt of stolen property" is a crime at all? Or from a case where he does know that a regulatory offense encompasses certain type of weapons or devices (or certain types of drugs or products) but does not know that it encompasses others?

In short, the distinction between mistake of governing law and of legal element is badly in need of clarification. ${ }^{20}$ And even the distinction between mistake of law and mistake of fact deserves more careful elucidation. ${ }^{21}$

\section{E. Clarify the meaning of the "reasonable person" test}

In a wide range of contexts, the MPC employs a "reasonable person" criterion. But the contours of the criterion are often unclear. First of all, how subjective is it? Which characteristics and capacities of the individual defendant are taken into account? Should we ask what the reasonable sixteen year-old would do or believe? The reasonable person in a state of shock? The reasonable hothead? The Code often fudges with the phrase, "[r]easonable person in the actor's situation."22 One can understand the Code's reluctance to provide a precise rule-

20 For some discussions of the difficulty of drawing and of justifying the distinction between mistake of legal element and mistake of governing law, see Gerald Leonard, Rape, Murder, and Formalism: What Happens if We Define Mistake of Law?, 72 U. CoLo. L. REV. 507 (2001); DRESSLER, supra note 8, at 173-77; Larry Alexander, Inculpatory and Exculpatory Mistakes and the Fact/Law Distinction: An Essay in Memory of Myke, 12 LAW \& PHIL. 33 (1993); Kenneth W. Simons, Mistake and Impossibility, Law and Fact, and Culpability: A Speculative Essay, 81 J. CRIM. L. \& CRIMINology 447 (1990).

21 See Leonard, supra note 20; Simons, supra note 20.

22 This phrase, or a similar one, occurs in the definitions of recklessness ("standard of conduct that a law-abiding person would observe in the actor's situation," MODEL PENAL CODE $\$ 2.02(2)(c)$ (1985)); negligence ("standard of care that a reasonable person would observe in the actor's situation," $\$ 2.02(2)(\mathrm{d})$ ); - extreme emotional disturbance, $\$ 210.3(1)(\mathrm{b})$ ("extreme emotional disturbance for which there is a reasonable explanation or excuse," where "the reasonableness of such explanation or excuse shall be determined from the viewpoint of a person in the actor's situation under the circumstances as believes them to be."); and duress, $\S 2.09$ (use or threat of force that "a person of reasonable firmness in his situation would have been unable to resist"). Moreover, a number of defenses incorporate negligence and recklessness criteria in the following way: if the actor makes a mistake in the exercise of a defense, his punishment is sometimes mitigated in proportion to the culpability of his mistake. See MODEL PENAL CODE $\S 3.09(2)$ (self-defense); $\$ 3.02(2)(2)$ (choice of evils).

The MPC Commentaries acknowledge that by employing this phrase, they create. a certain amount of vagueness, to be clarified by courts or resolved by juries. See MPC Commentaries, supra note 3, at 242 (describing ambiguity of "in the actor's situation" in definition of negligence); id. $\S 2.09$ at 375 ("situation" should be given same scope as in appraising recklessness and negligence; it should consider "[s]tark, tangible factors" such as "size, strength, age, or health," but not "[m]atters 
like criterion here, given the broad and diverse range of fact patterns to which the criterion must apply. Still, perhaps the Code could at least employ a standard, to provide some guidance on how subjective the test should be. It might, for example, adopt a standard along these lines: "The judge or jury may consider the actor's personal situation only when this has a just bearing on his culpability."

A second and related question is this: Does the "reasonable person" test change its meaning depending on the context? After all, some kind of reasonable person or reasonableness requirement appears in quite a range of contexts-not only as part of the prima facie case, but also in defenses; and not only in defenses, but in defenses of excuse (such as duress or extreme emotional disturbance) as well as defenses of justification (such as lesser evils or self-defense). ${ }^{23}$

But how does a "person of reasonable firmness" in duress compare to the "standard of conduct [observed by] a law-abiding person . . . in the actor's situation" in the definition of recklessness? ${ }^{24}$ The Code, alas, gives little guidance. In duress, for example, is the point of the "reasonableness" constraint to exclude the defense from actors who are especially blameworthy (i.e., whose excuse claim is weak)? From actors who, although not especially blameworthy, have unjustifiably committed a crime (i.e., whose acts, though excused, are not justified)? Or is the point, instead, the institutional imperative to avoid the risks of fraud and error that a broader defense would create, or the consequentialist concern not to weaken the deterrent efficacy of the criminal law?

Third, is the reasonable person criterion too cognitive? Insofar as the criterion can apply to result as well as circumstance elements - for example, to negligent homicide-perhaps the basic definition of negligence should encompass not only what a reasonable person would believe, but also what he or she would $d o{ }^{25}$ Thus,

of temperament"); id. $\S 210.3$ at $62-63$ ("reasonable explanation or excuse" is flexible, and "[t]he word 'situation' is designedly ambiguous," incorporating the defendant's "personal handicaps and some external characteristics," but excluding "idiosyncratic personal values"; however, the Commentators leave open whether "an abnormally fearful temperament" or abnormal sensitivities may be considered).

23 The MPC's "extreme emotional disturbance" provision poses a further problem. This provision is meant to include not only the voluntary manslaughter, "heat of passion" doctrine, but also cases of mental disability or illness less than insanity in which the offender deserves a partial excuse, i.e., a conviction of manslaughter rather than murder. But imposing a "reasonableness" qualification on both categories is extremely confusing, since the mentally disordered defendant cannot easily be characterized in "reasonable person" terms. By definition, a person with a peculiar mental disability or disturbance is not a "reasonable person." For cases revealing the awkwardness of employing a reasonableness test to encompass both heat of passion and mental disorder, see State v. Raguseo, 622 A.2d 519 (Conn. 1993) and People v. Casassa, 404 N.E.2d 1310 (N.Y. 1980).

24 The "reasonable person" component of the negligence standard is worded almost identically. It does not appear that the slight difference in wording was intended to mark a difference in meaning or scope. MPC Commentaries, supra note 3, at 242 n.27; Treiman, supra note 15, at 348-49.

${ }^{25}$ In some iterations, to be sure, the "reasonableness" requirement does focus on action, not belief. Consider the definitions of duress and extreme emotional distress. See MPC Commentaries, supra note 22. 
suppose a highly unskilled driver or surgeon causes an accident. Her fault might consist in departing greatly from the standard that a reasonable person would satisfy, and not, or not merely, in her failing to be aware of a substantial risk posed by her driving or by her surgical technique. (No doubt she is perfectly well aware that if she fails to react promptly to other drivers, or fails to keep a steady hand, she will pose a substantial risk of injury to others. ${ }^{26}$ ) In short, not all negligence involves perceptual difficulties, or even failures to make reasonable inferences from perceptions; yet the MPC criterion is limited to such cases.

\section{F. Clarify the definition of willful blindness, in subsection (7)}

The MPC's version of the willful blindness doctrine is as follows: "When knowledge of the existence of a particular fact is an element of an offense, such knowledge is established if a person is aware of a high probability of its existence, unless he actually believes that it does not exist." This provision raises a number of questions.

First, as noted above, the meaning of a "high" probability is unclear; although this must describe a greater risk than the "substantial" risk that the lesser mental state of recklessness requires, how much greater must the risk be? And how does it compare to the definition of knowledge as to a result, "practical certainty"?

Second, if "high probability" is greater than $50 \%$, then the definition as a whole appears to be incoherent. For the last clause that follows - "unless the actor actually believes that the fact does not exist"-would seemingly never apply. How can you actually believe that a fact does not exist, when you know that more likely than not, it does exist? Thus, suppose an actor is charged with knowingly transporting drugs, because she agrees to carry a suspicious package from a known drug supplier to another person for a large fee. How can she both think it likely that the package contains drugs, but also believe that it does not?

Third, this definition also does not further the supposed policy behind willful blindness-namely, to treat a reckless actor as harshly as a knowing actor in those cases where the reckless actor lacks knowledge only for a culpable reason. To be sure, there is a serious question whether a willful blindness approach to knowledge is ever justifiable, for it risks watering down the knowledge standard in too many cases. Absent a clear and defensible criterion of willful blindness, the approach could, in every case, permit a jury to find that defendant "knew" that a circumstance existed based simply on the defendant's recklessness as to the circumstance. But if the MPC means to adopt some version of the willful blindness approach, this provision is inartfully drafted.

26 See Kenneth W. Simons, Dimensions of Negligence in Criminal and Tort Law, 3 THEORETICAL INQUIRIES IN L. 283, 295-97 (2002). 
A revision of the Model Penal Code should consider these problems, among others. ${ }^{27}$ But now it is time to consider some difficulties posed by the MPC approach that are more fundamental.

\section{RECKLESSNESS}

The MPC's recklessness criterion is a laudable attempt to identify and clarify the minimum culpability presumptively required for criminal liability. It is a much more precise criterion than the common law "general intent" standard that it more or less replaces. ${ }^{28}$ And, as the default mens rea when the legislature didn't otherwise specify the mens rea for an offense element, it is a more stringent mens rea criterion than general intent (as most jurisdictions would interpret the latter term).

The commitment to use recklessness as the default criterion was a bold substantive decision, which could have significantly restricted criminal liability relative to the common law position. As it turns out, however, many states that adopted the MPC did not agree to use it as a default. ${ }^{29}$ Still, the MPC's decision to make recklessness the default mental state is important as a matter of principle. For it expresses the classic liberal idea that moral culpability is, and criminal liability should be, based on a conscious choice to do wrong.

However, the MPC's recklessness criterion raises a number of significant problems.

27 It would also be worth clarifying the default mens rea that applies to differences in the grade of offenses-for example, the quantity of drugs possessed. If liability depends on knowingly possessing an illegal drug, must one also know the amount or weight (within some range), if this fact significantly affects the punishment? (The New York Court of Appeals said "yes," but the legislature responded by rejecting this interpretation. See N.Y. PENAL LAW $\S 15.20(4)$; People v. Ryan, 626 N.E.2d 51, 54 (N.Y. 1993)). For discussion, see Peter W. Low, The Model Penal Code, the Common Law, and Mistakes of Fact: Recklessness, Negligence, or Strict Liability?, 19 RUTGERS L.J. 539, 546 (1988) and Richard Singer, The Model Penal Code and Three Two (Possibly Only One) Ways Courts Avoid Mens Rea, 4 BUfF. CRIM. L. REV. 139, 190-95 (2000).

Moreover, the MPC's current mistake of fact provision, $\S 2.04$, apparently has been misunderstood; in some states, the MPC's "logical relevance" approach has been undermined by inconsistent separate "mistake of fact" provisions that simply require that the mistake be "reasonable" (thus ignoring the MPC's distinction between negligent and reckless mistakes). Perhaps a revised MPC should omit the separate $\S 2.04(1)$ provision entirely. At the very least, the "logical relevance" approach needs to be explained more clearly. See Dannye Holley, The Influence of the Model Penal Code's Culpability Provisions on State Legislatures: A Study of Lost Opportunities, Including Abolishing the Mistake of Fact Doctrine, 27 Sw. U. L. REV. 229 (1997).

28 For a valiant effort to articulate the criteria of general and specific intent, see DRESSLER, supra note 8 , at $135-37$.

29 See MPC Commentaries, supra note 3, at 244-45 n.36; see also Holley, supra note 27, at 243-44 (noting that many states that have adopted the MPC model have no default; eleven follow the MPC in using recklessness as the default; six use negligence as the default; however, one uses the more stringent mental state of knowledge as the default). 


\section{A. Awareness of a "substantial and unjustifiable" risk}

The requirement that the defendant "consciously disregard a substantial and unjustifiable risk" is ambiguous. Must he be aware both that the risk is substantial and that it is unjustifiable? ${ }^{30}$ Moreover, are these independent requirements, or does the requisite "substantiality" of the risk also depend on how unjustifiable it is? $?^{31}$

With respect to the first question, it is fairly clear from the commentary (though not from the text) that the defendant needs to be aware only that the risk is substantial, not that it is unjustifiable. ${ }^{32}$ Indeed, redrafting of the MPC would be useful to clarify this point. ${ }^{33}$ The answer to the second question is less obvious, however. Consider two different possible answers.

1. Substantiality and unjustifiability are independent requirements, and "substantiality" is an invariant threshold requirement

On this view, the actor must be aware of, say, a $5 \%$ risk without regard to the type of harm or the unjustifiability of his conduct. In this sense, recklessness would be analogous to the MPC's other cognitive mental state, "knowledge." Of course, knowledge is indeed an invariant mental state; when it is required, the actor

30 A related question: Must the actor be aware merely of the facts that make the risk substantial, or must he also advert directly to the substantiality of the risk? (Similarly, must he be aware merely of the facts that make the risk unjustifiable, or must he also advert direct to its unjustifiability?) If, in either case, the first form of awareness suffices, then the recklessness test turns out to be much closer to a negligence test than one might have imagined.

With respect to consciousness that the risk is substantial, it is very likely that the second form of awareness is required. See Treiman, supra note 15 , at 358 . Suppose a speeding driver sees a pedestrian and says to his passenger "I think I can probably avoid him, but anyway, it's worth the risk." A jury could readily conclude that the driver has consciously adverted to a substantial risk of hitting him. (However, the driver need not have been aware of the legal term "substantial" so long as his actual conscious experience constitutes "awareness of a substantial risk.") On the other hand, it is implausible to require the second form of awareness in the case of unjustifiability: it should not be a defense that the actor believes it is justifiable to impose a particular type of risk on another. See Larry Alexander, Insufficient Concern: A Unified Conception of Criminal Liability, 88 CAL. L. REV. 931, 953 n.62 (2000). But see Joshua Dressler, Does One Mens Rea Fit All?: Thoughts on Alexander's Unified Conception of Criminal Culpability, 88 CAL. L. REV. 955, 959 (2000) ("I would define recklessness . . . in terms of risk-taking that is substantially or grossly unjustifiable, and I believe the law should require proof that the actor adverted to its very likely unjustifiability.").

31 For discussions of this question, see Alexander, supra note 30, at 933-35; Dressler, supra note 30 , at $956-59$.

32 Treiman, supra note 15 , at 362,365 . Treiman does point out that analysis of the unjustifiability of the risk, while a largely objective inquiry; contains a subjective component insofar as it considers the circumstances known to the actor. Id. at 365-67.

33 Some states have adopted a more perspicuous formulation-that recklessness requires the conscious and unjustifiable disregard of a substantial risk. Id. at 366. 
must be aware of a "high probability" or a "practical certainty," period, without regard to any other factors.

If this threshold view is correct, then, in order for an actor to be reckless as to causing bodily injury to another, he must be aware of at least (say) a 5\% risk that his blow will injure the victim. To be guilty of reckless manslaughter, he must be aware of at least a $5 \%$ risk that he will cause another's death. And to be guilty of reckless sale of liquor to a minor, he must be aware of at least a 5\% risk that the buyer is below age.

But suppose we don't view substantiality and unjustifiability as independent requirements? In other words, consider a second approach:

2. Substantiality depends on the degree of unjustifiability (and perhaps on other factors as well)

Perhaps an actor should be guilty of recklessly causing a death even if he is aware of only a tiny risk of death, less than any threshold "substantiality" requirement, if the risk is extremely unjustifiable. (Suppose he is drag-racing on what he reasonably thinks is an abandoned parking lot. Or suppose he shoots a gun in the air to frighten someone, and his action causes injury or death. ${ }^{34}$ )

Similarly, "substantiality" could vary according to factors other than the unjustifiability of the conduct. For example, it might vary according to the seriousness of the harm; thus, a $1 \%$ risk of death might count as "substantial," but if the relevant harm were merely personal injury, then nothing less than a $10 \%$ risk (of personal injury) would count as "substantial." two options the MPC drafters mean to endorse. In support of the first, the

34 See Alexander, supra note 30 , at 934 (posing the example of an extremely low probability Russian Roulette machine by which defendant deliberately poses a risk of death on an involuntary victim); Singer, supra note 27, at 193 (posing a similar example).

35 Thus, in People v. Hall, the Court held that whether a risk is "substantial" depends on both the probability of the risk and the magnitude of the harm if the risk occurs.

Some risks may be substantial even if they carry a low degree of probability because the magnitude of the harm is potentially great. For example, if a person holds a revolver with a single bullet in one of the chambers, points the gun at another's head and pulls the trigger, then the risk of death is substantial even though the odds that death will result are no better than one in six. . . Conversely, a relatively high probability that a very minor harm will occur probably does not involve a "substantial" risk. Thus, in order to determine whether a risk is substantial, the court must consider both the likelihood that harm will occur and the magnitude of potential harm, mindful that a risk may be "substantial" even if the odds of the harm occurring are lower than fifty percent.

999 P.2d 207, 217-18 (Colo. 2000).

Alexander believes that recklessness should not require awareness of a "substantial" risk. Rather, he suggests, recklessness should be understood as a sliding scale: knowingly imposing even a tiny risk can be reckless if the risk is extremely unjustifiable, while knowingly imposing even a substantial risk can be justifiable. Alexander, supra note 30 . 
commentaries speak of the requirement of awareness of a substantial risk, ${ }^{36}$ but never speak of any required awareness that the risk is unjustifiable. ${ }^{37}$ In support of the second, the commentaries contain one footnote suggesting that substantiality depends to some extent on justifiability: "[L]ess substantial risks might suffice for liability if there is no pretense of any justification for running the risk."

This problem has been underappreciated. And it is related to another ambiguity: can an actor be aware of a risk and yet be merely "negligent" (for purposes of the MPC classification) rather than reckless? Under the first interpretation, especially, this is a real possibility. For an actor might believe he is posing only an insubstantial risk. Although the distinction between recklessness and negligence is almost always treated (in the MPC commentary, in judicial opinions, and in academic writings) as a distinction between awareness and inadvertence, ${ }^{39}$ there is an important third possible category-namely, where an actor realizes that he is creating some risk, but concludes (either reasonably or unreasonably) that the risk is tiny and insubstantial. (Imagine a speeding driver supremely confident that he has the skill to avoid a collision. ${ }^{40}$ ) Should such an actor really be treated as merely negligent, not reckless? Especially if he was unreasonable in inferring that the risk was insubstantial? Courts in MPC jurisdictions appear to have reached different conclusions. ${ }^{41}$

36 MPC Commentaries, supra note 3, at 236, n.13.

37 One passage is quite ambiguous:

[The jury] is to examine the risk and the factors that are relevant to how substantial it was and to the justifications for taking it. In each instance, the question is asked from the point of view of the actor's perceptions, i.e., to what extent he was aware of risk, of factors relating to its substantiality and of factors relating to its unjustifiability.

Id. at 238. Does the last sentence mean that the jury must find some awareness not only of risk, but of "substantiality" and of "unjustifiability"? If so, how much and what type of awareness?

38 Id. at 237 n. 14 .

39 See, e.g., id. at 240 (stating flatly that "negligence . . is distinguished from purposeful, knowing or reckless action in that it does not involve a state of awareness").

40 See Sanford H. Kadish \& Stephen J. Schulhofer, Criminal Law and Its Processes: CASES AND MATERIALS 215 (7th ed. 2001).

41 In People v. Strong, defendant claimed (based on past experience) to have special powers whereby he could stop a person's heartbeat and then stab the person in the chest without causing harm. He inserted three knives and a hatchet into the victim's chest. His "powers" failed him; the victim died. The New York Court of Appeals held that the jury should have been instructed on negligent homicide as well as reckless manslaughter, because the jury "could have found that the defendant failed to perceive the risk inherent in his actions." 338 N.E.2d 602, 604 (N.Y. 1975). And in In re William $G$., the court was persuaded that a youth who mistakenly believed that he had the skill to ride a shopping cart on two wheels in a busy parking lot without hitting a car lacked conscious awareness of the risk of damaging the property of another. 963 P.2d 287, 292 (Ariz. Ct. App. 1997).

However, in a Texas case, the court upheld a verdict of reckless manslaughter when the victim challenged defendant to see if she could flip open a knife faster than defendant could draw a loaded gun. Yates v. State, 624 S.W.2d 817, 817 (Tex. Crim. App. 1981). The court seems to find irrelevant whether the defendant thought the risk of death from this "quick-draw" game was minimal. 
One possible solution to these difficulties is simply to drop the "substantiality" requirement from the definition of recklessness: the actor would need to consciously disregard "a risk," but not "a substantial risk." (Of course, the "unjustifiable" requirement would remain.) This approach might be less precise than an invariant threshold requirement, but arguably it better serves the twin policies underlying the MPC's recklessness criterion-namely, requiring some awareness of risk while asking the trier of fact to make a broad evaluative judgment of the actor's culpability in taking the risk.

\section{B. What does "conscious" disregard mean?}

What type or degree of "consciousness" is required? This is a significant problem for the mens rea of knowledge as well as for recklessness. ${ }^{42}$

Thus, suppose you know something, or you are aware of a risk, but at the moment when you cause the harm, you have forgotten what you knew, or you are distracted? $?^{43}$

And what aspects of the risk must you be "aware" of? Suppose you are driving and approach a light that has just turned red. And suppose (as is certainly the case) you are aware that it is risky to run the red light, but you are unaware that a pedestrian is nearby. Are you reckless as to the risk of injuring or killing him $?^{44}$

If, to be reckless, you must actually be aware of the presence of the pedestrian, then quite a few actors who have some awareness of risk 'won't be considered reckless under the MPC. ${ }^{45}$ But, on the other hand, if it is enough that

I take it for granted that in this third category, where the actor is aware of an insubstantial risk and satisfies the other requirements of both negligence and recklessness (unjustifiability and gross deviation), the actor should at least be considered negligent.

42 See Bruce Ledewitz, Mr. Carroll's Mental State or What is Meant by Intent, 38 AM. CRIM. L. Rev. 71 (2001); see also Samuel H. Pillsbury, Judging Evil: Rethinking the Law of Murder AND MANSLAUGHTER 166-71 (1998). Moreover, the question whether an actor must be "conscious" of his actions is also relevant to the threshold determination whether he has committed a voluntary act. For a thorough recent analysis of this issue, see Deborah W. Denno, Crime and Consciousness. Science and Involuntary Acts, 87 MINN. L. REV. 269 (2002).

43 If a bank robber forgets that he is carrying a loaded gun with him, is he exculpated from an aggravated form of bank robbery that requires "knowingly carrying a loaded gun during the course of the robbery"? This hardly seems like a justifiable excuse. On the other hand, if a parent forgets that his young child is alone in his car while the parent goes shopping, with the result that the child suffers harm, does the parent escape liability for recklessly causing that harm? This result seems more justifiable. But is the distinction between the two cases defensible? On the question of the legal relevance of forgetting, see Eric Colvin, Recklessness and Criminal Negligence, 32 U. TORONTO L.J. 345, 368-69 (1982); James B. Brady, Recklessness, 15 L. \& PHIL. 183, 188-89 (1996). (2001).

44 See Kimberly Kessler Ferzan, Opaque Recklessness, 91 J. Crim. L. \& CriminOlogy 597

45 In Ferzan's terminology, such actors will be merely "opaquely" reckless. See id. Or consider the straightforward case of a careful driver who swerves to avoid a bicyclist. His only conscious thought might be "get out of the way of the bike"; nevertheless, it might be reasonable to conclude 
you are aware that a certain kind of conduct is in general pretty risky, then many, or perhaps most, cases of negligence become cases of recklessness! Suppose you are distracted while driving because you are talking on your cell phone, or because you lose your temper, or because you are preoccupied thinking about a lost love. Are these all reckless acts? For you undoubtedly know that if you become distracted in one of these ways while driving, you might well cause an accident. But if these examples count as "recklessness as to resulting harm," then so do a wide range of cases in which the actor, although unaware of the specific risk, is aware that the type of conduct he carelessly engaged in could be dangerous.

This problem is not merely academic. In a Texas case, the defendant was found guilty of reckless manslaughter for speeding and driving in the opposite lane, even though she was not actually aware of the presence of the vehicle that she crashed into, since the collision occurred at the crest of a hill. ${ }^{46}$ In another Texas case, the court upheld a verdict for reckless manslaughter despite the possibility that the defendant fell asleep at the wheel and thus was unaware of the risk of death in the moments just prior to the accident. ${ }^{47}$ And in a Colorado case, the court found sufficient evidence of reckless child abuse for recklessly endangering a child when defendant crashed into another vehicle that contained several children, although defendant was not aware of this fact prior to the collision. In the court's view:

[T] he awareness required for reckless child abuse is simply the risk that one's conduct could result in an injury to a child's life or health [citing statute]. Therefore, the risk in this case was not that children might be in the actual car that Deskins' vehicle hit that night. On the contrary, what Deskins consciously disregarded when he drove while drunk was the risk that children would be passengers in any of the cars on the road that night. ${ }^{48}$

that he was aware, at a preconscious level, of the risk that the bicyclist will fall if the driver does not switch lanes. Id. at 629-30.

Accordingly, Ferzan has suggested that, if an actor is consciously aware merely that her conduct is dangerous, she can be considered reckless even if she is only preconsciously aware of why her conduct is dangerous (e.g., because running a red light could kill a pedestrian). Id. at 644 .

46 Newman v. State, 49 S.W.3d 577 (Tex. App. 2001).

47 In the court's words: "The jury could properly apply recklessness to the act of driving generally, and need not have focused its attention only to the instant before the collision or to whether or not appellant knew he was across the line." Porter v. State, 969 S.W.2d 60, 63 (Tex. App. 1998).

48 People v. Deskins, 927 P.2d 368, 373 (Colo. 1996). 


\section{Does a strict "consciousness" requirement undermine the rule that ignorance of the law is no excuse?}

Here is the problem. Suppose the actor gives no thought to the risk, but the reason he fails to consider the risk is that he has no idea that the law punishes such an act. For example, suppose a law punishes "knowingly" or "recklessly" possessing a shotgun of a length less than 18 inches. $^{49}$ If you don't even know there is such a law, you are unlikely to have any conscious beliefs about its application to your conduct; yet that would mean that ignorance of law would, as a practical matter, provide you with a defense of lack of mens rea! ${ }^{50}$

If we continue to hold to the view that ignorance of the law is no excuse, this is a discomfiting result. For it implies that actors who are diligent enough to ascertain the legal requirements that govern their actions are more likely to be guilty than those who are indifferent to those requirements.

\section{The problem of "latent" knowledge}

Should we employ a counterfactual test, here or in some of the other cases, and try to discover the actor's latent beliefs? Perhaps we should ask, "If defendant gave the matter a moment's thought, what would he have concluded about the fact, or about the risk?"51 (If you considered the question of the length of the gun in your possession even for a moment, you would acknowledge that the gun is less than a foot long.)

After all, many criminal acts are done quickly or impulsively, without much self-conscious thought of any sort, much less conscious advertence to risks of resulting harm. Thus, suppose I get into an argument with you. You insult me. Instantly, I give you a shove. You stumble and hurt your knee. Am I "conscious of a substantial risk that I will cause you bodily injury"? Perhaps I gave no

49 See State v. Young, 965 P.2d 37, 45-46 (Ariz. Ct. App. 1998); State v. Jordan, 733 N.E.2d 601,607 (Ohio 2000) (reasoning that "knowledge" does apply to the element "dangerous ordnance," and that the latter, as applied, requires that the shotgun have a barrel less than 18 inches in length; but concluding that the actor need only "know or be aware of the probability that the item in his possession is dangerous," not that the shotgun was shorter than 18 inches).

50 For discussions of this problem, see JOHN CYRIL SMITH \& BRIAN Hogan, CRIMINAL LAW 72 (9th ed. 1999); Glanville Williams, CRiminal Law: The General Part 44-48, 154-56, 160-61 (2d ed. 1961); Robert Batey, Judicial Exploitation of Mens Rea Confusion, at Common Law and under the Model Penal Code, 18 GA. ST. U. L. REV. 341, 405-10 (2001); Leonard, supra note 20, at 527-34.

51 See ANDrew Ashworth, Principles of Criminal LAW 185-86 (3d ed. 1999); Jeremy Horder, Gross Negligence and Criminal Culpability, 47 U. ToronTo L.J. 495, 510-13 (1997); Kenneth W. Simons, Culpability and Retributive Theory: the Problem of Criminal Negligence, $5 \mathrm{~J}$. CONTEMP. LEgAL IsSUES 365, 384-85 (1994); see also Alexander, supra note 30, at 953 n.62. Similarly, if an actor is aware that he has little idea what the risk is, perhaps his uncertain state of mind is properly characterized as "consciousness of a substantial risk," at least where he realizes that the risk could well be substantial. See Treiman, supra note 15, at 324 . 
explicit, conscious thought at all to the consequences of my actions. But am I really no worse than negligent as to the resulting harm?

Similarly, actors often give little or no conscious thought to circumstantial aspects of their conduct, especially if those aspects don't affect their basic intentions and plans. Thus, suppose I'm committing a burglary, entering a building from the outside, well after dark. I might well give no thought at all to whether it is day or night. Nevertheless, virtually any sighted person in my shoes will know that it is dark out, even though he is unlikely to consciously advert to the question. If burglary requires that the actor be reckless as to the risk that he is entering a house at nighttime, should I really be exculpated, simply because I'm not thinking about this circumstance at the time?

One solution is to distinguish between belief and knowledge, on the one hand, and consciousness and awareness, on the other. At this very moment, I know that the Earth is round, that I have ten fingers, and that the United States is not at war with Russia, but it might not be accurate to say that I am conscious or aware of any of these facts. ${ }^{52}$ And perhaps the distinctive culpability of recklessness should require consciousness, not this weaker type of knowledge. On the other hand, it is doubtful that the MPC meant its definition of knowledge to require less in the way of consciousness than its definition of recklessness; indeed, the Commentaries clearly distinguish recklessness from knowledge in terms of how probable the actor believes the element to be, not in terms of different degrees or types of consciousness.

Another solution is to recognize certain cases of immediately-accessible latent knowledge as satisfying criminal law cognitive standards (of both recklessness and knowledge). Still, by recognizing such cases, we partly eviscerate the line between subjective and objective, between "adverted" to the risk and "should have been aware" of the risk. The solution, I suspect, will not be simple.

\section{DOES THE MODEl PENAL CODE HIERARCHY ALWAYS WORK?}

The MPC views its four basic mental states or culpability terms as hierarchically ordered: all else being equal, purpose is more culpable than knowledge, which is more culpable than recklessness, which is more culpable than negligence. Indeed, the MPC explicitly provides that if a statute requires a mental state that is lower in the hierarchy, then an actor who possesses a higher mental state also satisfies that mental state requirement. ${ }^{53}$

52 See R.A. Duff, Intentions, ACtions, ANd Criminal Liability $164-65$ (1990); John R. SEARLE, INTENTIONALITY: AN ESSAY IN THE PHILOSOPHY OF MIND 141-59 (1983); Treiman, supra note 15, at 354 (distinguishing knowledge from consciousness and belief).

53 MOdel Penal CODE $§ 2.02(5)$ (1985). 
But is this hierarchy defensible? ${ }^{54} \mathrm{~A}$ first set of questions asks whether knowledge is always "worse" than recklessness, and whether recklessness is always "worse" than negligence. A second inquiry is whether the mental state categories in the hierarchy are excessively cognitive, excessively descriptive, or too rigidly defined.

\section{A. Is knowledge always worse than recklessness? Is recklessness always worse than negligence?}

Consider, first, whether knowledge is invariably worse than recklessness. In two recognized doctrinal categories, the answer is "no." The willful blindness doctrine essentially provides that some actors who are merely reckless as to a circumstance element of a crime (such as whether they are transporting drugs) deserve the same punishment as actors who know that the circumstance existsnamely, those reckless actors who lack knowledge that the risk is very likely only because they deliberately avoid such knowledge. ${ }^{55}$ And the extreme indifference murder category essentially provides that some actors who are merely reckless as to the resulting death deserve the same punishment as actors who intend to cause death or who know that they will very likely cause death-namely, those reckless actors whose actions and motives display "extreme indifference to the value of human life" or a "depraved heart." For example, someone who shoots a gun into an occupied house might only be reckless, not knowing, as to the risk that death will result, but he still might be classified as a murderer under this category.

Interestingly enough, the MPC itself recognizes "extreme indifference" murder, thus departing from its commitment to limit mens rea to the four categories in the hierarchy. Both the willful blindness doctrine (which the MPC recognizes only to a limited extent ${ }^{56}$ ) and the extreme indifference doctrine suggest that the cognitive focus of the knowledge/recklessness distinction is too narrow. These doctrines demonstrate that criminal culpability is not merely a function of how great a risk an actor believes he is running; it also depends on: (1) why he believes that he is running only a smaller risk (is he deliberately avoiding greater knowledge?), and (2) whether his motives and other features of his conduct make him especially culpable.

54 For some discussions, see Douglas Husak, The Sequential Principle of Relative Culpability, 1 LEGAL THEORY 493 (1995); Alexander, supra note 30; Simons, supra note 8.

55 For some discussions, see DRESSLER, supra note 8, at $125 \mathrm{n} .62$ (collecting sources). On one view, willful blindness should be limited to those reckless actors who would act the same way even if they did possess knowledge. See Michaels, supra note 12, at 995-1002.

56 As noted above, the MPC recognizes a version of this doctrine that is confusingly drafted and apparently narrower than the version adopted by many courts. The MPC's requirement that the actor believe the fact is highly probable is more stringent than the more common requirement that the actor simply suspect that the fact exists. 
Just as knowledge is not invariably "worse" than recklessness, recklessness is not always worse than negligence. ${ }^{57}$ Here, too, some negligent, inadvertent actors might act with a state of mind that is as blameworthy and worthy of punishment as reckless actors who are aware of the risks. Thus, some states have traditionally used some version of "culpable indifference" as the mens rea of manslaughter, without requiring conscious awareness of the risk of death. ${ }^{58}$ Moreover, when an actor is intoxicated and for that reason is unaware of a relevant risk, he is usually treated as "constructively" reckless, i.e., he is treated as harshly as a sober actor who is actually aware of the relevant risk. Even the Model Penal Code, which generally abhors imputed or constructive mental states, adopts a constructive recklessness approach to intoxication. ${ }^{59}$

Perhaps, then, the definition of recklessness should be expanded generally to include not only actors aware of the relevant risks, but also actors who are "culpably indifferent" to the resulting harm or the unlawful circumstance. And this wider criterion could take into account why the actor was unaware of a risk, or why he discounted the risk and considered it insubstantial. If it is because he is intoxicated, of course, even the MPC deems him as culpable as a reckless actor. But one might expand this equivalence beyond intoxication. For example, suppose he lacked awareness for a different, but similarly culpable, reason-because he was preoccupied with committing a crime or because he lost his temper? ${ }^{60}$ On the other hand, his reason for unawareness might be much more sympathetic: suppose a driver has just heard about the death of a loved one and thus is in an understandable state of shock and grief. ${ }^{61}$

57 See GeORge P. FletCHER, BASIC CONCEPTS OF CRIMINAL LAW 116 (1998) (arguing that an automobile manufacturer which negligently fails to investigate safety risks at all is more culpable than a manufacturer which investigates the risks but makes an improper trade-off of cost against safety); DUFF, supra note 52, at 157-73; Horder, supra note 51, at 508; Simons, supra note 51.

58 See Batey, supra note 50, at 379-80; Simons, supra note 8, at 489.

59 Model Penal Code $§ 2.08$ (2) (1985).

60 See Glanville Williams, The Unresolved Problem of Recklessness, 8 LEGAL STUDies 74, 86 (1988).

61 And, by the same token, some reckless actors perhaps should be considered less culpable, and no more culpable than negligent actors, if they act for an especially exculpatory motive - such as a desire to minimize the risk of harm, or to relieve the suffering of another.

Some have suggested that the MPC's language of conscious "disregard" requires some additional culpability beyond simply choosing to take the risk in the face of awareness of a substantial and unjustifiable risk. Thus, Markus Dubber thinks that this language might imply culpable indifference or acceptance (dolus eventualis), and not the less culpable mens rea of merely acting despite awareness (mere culpa). DUBBER, supra note 6, at 75 . And David Treiman argues that genuine efforts to minimize a risk can sometimes negate the requisite "disregard," though it is not clear that he would apply this analysis when the actor's efforts succeed in lowering the risk but the actor recognizes that the residual risk is still substantial. Treiman, supra note 15, at 370-71. Moreover, in a recent New York case, the Court of Appeals reasoned that because the defendant employer consulted with city officials and warned workers to avoid a dangerous pressurized water pipe, they were not guilty of reckless endangerment. "Thus, defendants did not disregard a risk. On the contrary, they took steps to avert it." People v. Reagan, 723 N.E.2d 55, 56 (N.Y. 1999). 
On the other hand, employing "culpable indifference" or a similar standard as a mens rea category creates its own set of problems, both in its aggravated, "extreme" form, elevating recklessness to knowledge, and in its more modest form, elevating negligence to recklessness. On its face, the criterion is quite vague, and would require careful articulation in order to avoid inconsistent and arbitrary application. ${ }^{62}$ The willful blindness and extreme indifference murder categories have proven problematic in this respect. It would be similarly problematic to expand the definition of recklessness to encompass not just actors who were aware of the risk but also those who were, say, "unaware of the risk for a seriously culpable reason."

Moreover, used loosely, the criterion would permit punishment merely for bad character, not for acts. For it might justify punishing someone merely for his disreputable attitude of indifference towards the risk or harm, even if that attitude did not actually affect his course of conduct. Imagine a driver who negligently fails to pay attention while backing out of his driveway, and who accidentally runs over a child. Suppose he responds to the tragedy with laughter or even delight. His response is morally despicable but hardly the proper basis for criminal punishment. $^{63}$

A more radical approach to the MPC hierarchy is to replace it entirely, either with multiple hierarchies ${ }^{64}$ or with a single (though complex) mental state. ${ }^{65}$ However, whatever the intellectual merits ${ }^{66}$ of these ideas, implementing them in a revised MPC is not a realistic prospect.

\section{B. The MPC categories: Too cognitive? Too descriptive? Too rigid?}

Let us turn to a related set of concerns about the MPC culpability provisions. First, are the MPC's categories too cognitive? The recklessness criterion, for example, which is the default minimum culpability for any element, emphasizes the actor's awareness of a risk. As we have seen, however, the focus on consciousness of a risk is problematic in many cases. The standard is difficult to

62 See Michaels, supra note 12, at 955 (offering his conception of "acceptance" as a solution to these problems with both willful blindness doctrine and extreme indifference murder doctrine); Simons, supra note 51; Ferzan, supra note 44, at 624-25; Robin Charlow, Bad Acts in Search of a Mens Rea: Anatomy of a Rape, 71 FordHAM L. REV. 263, 323-24 (2002).

63 See Simons, supra note 10, at 220-21, 260-67.

64 See Simons, supra note 8, at 465, 476-94 (arguing that the MPC hierarchy should, in principle, be replaced by two hierarchies (of "belief-states" and "desire-states") plus a third hierarchy of more or less faulty "conduct").

65 See Alexander, supra note 30, at 944 (arguing for a single, sliding-scale standard of "insufficient concern").

66 Or demerits. For criticism of Simons' approach, see Kimberly Kessler Ferzan, Don't Abandon the Model Penal Code Yet! Thinking Through Simons' Rethinking, 6 BUfF. CRIM. L. ReV. 185 (2002). For criticism of Alexander's approach, see Dressler, supra note 30 . I have heard, from good authority, that Professor Simons plans to respond to Ferzan's criticisms in the near future. 
apply. Moreover, if a person lacks awareness of a risk only because he doesn't care at all about it, we might conclude that he is as culpable as one who is aware but makes efforts to avoid or minimize the risk (efforts that are grossly inadequate) ${ }^{67}$ Similarly, the negligence test is essentially defined negatively, in terms of risks of which the actor should have been aware. But sometimes, it is useful to employ a concept of negligence that focuses more on highly deficient skill than on culpable inadvertence. ${ }^{68}$

Second, are the MPC's categories too descriptive? Perhaps the culpability provisions should be more thoroughly and explicitly evaluative, requiring the trier of fact to make a direct moral judgment about the wrongfulness of the conduct. (Traditional mens rea categories often embodied this more explicitly evaluative approach. ${ }^{69}$ )

The MPC's current provisions are a mix of descriptive and more evaluative criteria. $^{70}$ Purpose and knowledge are fully descriptive. The "conscious . . of a substantial risk" component of the recklessness criterion is descriptive, while the "unjustifiable" risk and "gross deviation" language are evaluative. Negligence is a fully evaluative criterion, as is "extreme indifference" murder (except insofar as that criterion also requires recklessness). ${ }^{71}$

But should the MPC tilt more in the evaluative direction? For example, should the general definition of recklessness expand to include inadvertent actors if those actors are inadvertent "only for a seriously culpable reason (including, but not limited to, intoxication)"? Such a reorientation would bring both advantages and disadvantages. The disadvantages-and the concomitant benefits of a more descriptive approach-include the following: descriptive criteria are usually easier to apply; the jury applying them is less likely to import its own values; and the evaluative dimension can still be adequately expressed by manipulating actus reus

67 Compare a merely negligent babysitter who makes no effort to check whether a baby is safe, and thus lacks awareness of any risk to the baby's health, with a reckless babysitter who unreasonably decides to leave the baby unattended on the bed for a minute while she helps another child. Is the first babysitter really less culpable than the second?

68 See supra notes 25-26 and accompanying text. Similarly, the MPC employs a sanitized, cognitive version of willful blindness, as we have seen. Unlike the common law, the MPC pays no explicit attention to whether the actor's reason for possessing a mental state less than knowledge is culpable.

69 See Martin R. Gardner, The Mens Rea Enigma: Observations on the Role of Motive in the Criminal Law Past and Present, 1993 UTAH L. Rev. 635 (1993); Francis Bowes Sayre, Mens Rea, 45 HARV. L. REv. 974 (1932).

70 See Alan C. Michaels, "Rationales" of Criminal Law Then and Now: For a Judgmental Descriptivism, 100 COLUM. L. ReV. 54, 64-66 (2000); PILlSBURY, supra note 42, at 83-86.

71 See MPC Commentaries, supra note $3, \S 210.2$, at 22:

Whether recklessness is so extreme that it demonstrates similar indifference [to that displayed by purposeful or knowing homicide] is not a question ... that can be further clarified. It must be left directly to the trier of fact under instructions which make it clear that recklessness that can fairly be assimilated to purpose or knowledge should be treated as murder. 
elements. (Thus, instead of "extreme indifference" murder being defined as causation of death when the actor possesses that explicitly evaluative mental state, a similar category of murder might be defined as causing death as a result of purposefully causing harm or risk of harm to another, or as a result of knowing use of a deadly weapon.)

The advantages of the more evaluative approach, relative to a more descriptive approach, include greater honesty (at least, if one believes that the main purpose of employing one mens rea standard rather than another is to assess culpability); a closer fit between the judgments made under the evaluative criterion and the policies that the criterion is intended to serve or express; ${ }^{72}$ and a greater reliance on the community's judgment of the seriousness of the defendant's wrong, insofar as the evaluative criteria explicitly call for such a judgment. ${ }^{73}$

Third, are the MPC's criteria too rigid? The predominant MPC approach is an insistence that the legislature define substantive criminal law criteria (including mens rea criteria) very clearly, once and for all, at least until the legislature decides to amend the law. This approach is consistent with the general policy of legislative crime definition and fair notice to potential offenders.

But do we lose something with this approach? Should we avoid an overly rigid, predefined set of mens rea criteria? Should courts play a larger role in interpreting and refining these criteria over time? Would this afford the benefits of sensitivity to factually changing contexts, and responsiveness to changing values? $^{74}$

On the other hand, the legality concerns here are quite serious. Criminal defendants deserve fair warning of the criteria that will be applied, especially when the effect on the quantum of punishment can be enormous. (For example, the decision whether the actor who causes a death displays "recklessness plus extreme indifference" or merely recklessness marks the distinction between murder and manslaughter. ${ }^{75}$ )

72 Of course, it is also the case that the more vague the evaluative criterion, the more difficulty a fact-finder will have applying it accurately, i.e., in a way that furthers or expresses the policies underlying it.

73 See Simons, supra note 26, at 315-17.

74 For an affirmative response to these questions, see George Fletcher, Dogmas of the Model Penal Code, 2 Buff. Crim. L. REV. 3 (1998). For more negative responses, see Paul Robinson, In Defense of the Model Penal Code: A Reply to Professor Fletcher, 2 BUFF. CRIM. L. REV. 25 (1998); Batey, supra note 50; and Michaels, supra note 70 (arguing for "judgmental descriptivism," under which the fact-finder applies a clear descriptive criterion that nonetheless performs the function of expressing a judgment of moral blameworthiness).

75 The Commentaries to the MPC criticize the traditional "malice aforethought" approach for permitting an excessive judicial power to redefine the scope of homicide. MPC Commentaries, supra note $3, \S 210.2$ at 14 . The MPC's own criterion of extreme indifference murder avoids this problem, but only at the cost of leaving extraordinary discretion with the jury. See MPC Commentaries, supra note 71 . 


\section{CONCLUSION}

A skeptic might ask: "So what? ${ }^{76}$ Is improving the MPC's mens rea criteria really so important?" I close with two different responses.

\section{A. Mens Rea versus Actus Reus}

The first response is to agree, in part, with the skeptic. It is indeed worth considering whether mens rea is really the foundational, critically important element of substantive criminal law that criminal law scholars usually assume it to be. The question is a relative one: How important is mens rea relative to actus reus in a given jurisdiction's criminal code? And in an ideal code, how important would it be?

Do we in the academy overstate the relative importance of mens rea? After all, legislators normally pay much more attention to actus reus elements when they create new crimes, and (often) even when they differentiate degrees of a crime.

For example, rape and sexual assault crimes have recently received a great deal of legislative attention. But the debate is mainly over what the law should require in the way of force, or threats of harm or disadvantage, or incapacities in the victim, or expressions of nonconsent, and not over what mens rea should be required. ${ }^{77}$

Moreover, in the grading of different degrees of a crime, it is rare for a crime to use all mens rea categories-or even more than two. ${ }^{78}$.Indeed, often only one mens rea category is employed, and the grading is accomplished according to objective actus reus criteria, such as harm done, or the amount of drugs possessed, or the status of the individual who was assaulted, deceived or bribed..$^{79}$

To be sure, mental state distinctions are crucial in differentiating degrees of homicide. But homicide is an unusual crime in this respect. In assuming that mens rea is critically important in criminal law, we might forget that homicide is the only crime whose grades are differentiated solely according to variations in mens rea. And even in homicide, the role of mens rea is not as dominant as first appears. Thus, consider the legislative criteria for determining which murders

\footnotetext{
76 Or, as my children would put the question: "And your point is ...?"

77 Some commentators have endorsed differentiating degrees of sexual assault according to the actor's mens rea. See, e.g., StePhen J. Schulhofer, Unwanted Sex: The Culture of INTIMIDATION AND THE FAILURE OF LAW 284 (1998). But legislatures and courts have not been terribly receptive to this approach. Increasingly, it seems, courts either narrow the types of mistakes as to nonconsent that are recognized as defenses, or simply impose strict liability. See Joshua Dressler, Where We Have Been, and Where We Might Be Going: Some Cautionary Reflections on Rape Law Reform, 46 ClEV. ST. L. REV. 409, 430-39 (1998). And in many jurisdictions, it is even difficult to determine what mens rea is currently required. See Charlow, supra note 62, at 272-82.

78 See Husak, supra note 54, at 503-04.

79 The criminal legislation of most states is replete with such differentiations. See Singer, supra note 27 , at $183-87$.
} 
shall receive the death penalty. Many of the aggravating factors that states specify are not mental states. ${ }^{80}$ Moreover, felony-murder, which usually requires no explicit mens rea as to death, is still very much alive. And, although the doctrine has been restricted in many states, the restrictions often take the form of causal or other actus reus limits, not mens rea limits. ${ }^{81}$

The upshot? We would benefit greatly from a systematic analysis of the culpability structure of the special part of the criminal law, and of the various types and degrees of social harm. In analyzing the different types of theft, or of sexual assault, or of corporate fraud, how can we best explain and justify grading distinctions, holding constant the actor's state of mind? I do not imagine that a structure as straightforward and hierarchical as the MPC's four mental states will suffice, for at least two reasons. First, at the normative level, neither retributivists nor utilitarians are likely to reach easy agreement among themselves (much less between themselves) on the seriousness of various social harms. ${ }^{82}$ Second, at the pragmatic level, it is a political reality that legislatures feel the need to respond immediately when the public becomes upset about a sensational criminal incident or about a perceived upsurge in any type of criminal activity. These responses invariably take the form either of adding new actus reus elements to existing crimes, or of creating new crimes with new actus reus elements. (Only very rarely does this political reaction result in modification of a mens rea element. ${ }^{83}$ ) But the responses are often short-sighted and haphazard, and they tend to undermine any classificatory order within the special part that recodification might have initially achieved. $^{84}$

Nevertheless, at the very least, codifiers should follow the lead of the MPC's special part and systematize the categories of offenses into distinct groups of

80 Such non-mental state factors often include the victim's status (very young; elderly; police or correctional officer); the offender's status as an inmate; previous conviction of specified crimes; and whether the killing occurred in the course of a specified felony.

81 See DRESSLER, supra note 8, at 519-26; see also Guyora Binder, Felony Murder and Mens Rea Default Rules: A Study in Statutory Interpretation, 4 BUFF. CRIM. L. REV. 399 (2000) (noting that most states with MPC-based codes have ignored the possibility that as a result of their default mens rea requirements of negligence or recklessness, their felony-murder provisions might no longer be so strict).

82 To be sure, neither the retributivist nor the utilitarian camp has achieved unanimity about mental states either, but they have achieved a semblance of agreement.

83 For an example of this unusual situation, see CAL. PENAL CODE $\S 181$ (legislatively overruling a judicial opinion that narrowly interpreted the "malice" required for murder). Another example is the legislative movement to restrict the insanity defense following the John Hinckley verdict.

${ }^{84}$ Paul Robinson and Michael Cahill, in their article in this issue, point out, and appropriately criticize, the tendency of state criminal codes to grow "barnacles" over time that conceal whatever simple, logical shape the special part might have had when modern codification first took effect. Paul H. Robinson \& Michael T. Cahill, Can a Model Penal Code Second Save the States From Themselves?, 1 OHIO ST. J. CRIM. L. 169, 172 (2003). 
related crimes. ${ }^{85}$ More ambitiously, they might address a deeper question about the structure of criminal culpability: Is culpability better expressed by multiplying and refining mental state categories while simplifying and reducing the number of actus reus elements, or instead by moving in the opposite direction, i.e., simplifying mental state categories and multiplying actus reus terms? ${ }^{86}$

\section{B. Mens Rea and politics}

The second observation is that clarifying and improving the MPC's mens rea categories, helpful as it would be, will not address the most important problems with the contemporary state of substantive criminal law. Criminal punishments are frequently overly harsh: examples include three strikes laws; high penalties for even minor drug offenses; inflexible, high minimum penalties in many other categories; and significant punishment for even minor participants in criminal activities and enterprises. It is easy to draw the pessimistic conclusion that a model code drafted by the American Law Institute has no hope of countering the powerful bipartisan political imperative to "get tough on crime." Indeed, when we examine more closely the results in states that looked to the MPC in recodifying their criminal codes, it is clear that some of the MPC's aspirations to mitigate the excessive punitiveness of criminal legislation have not been met. For example, the felony murder rule is still widely enforced; more generally, strict liability continues to be quite prevalent, notwithstanding the MPC's strong disapproval; and negligence rather than recklessness is often the default mens rea requirement.

Could a Model Penal Code Second ameliorate these problems? Stronger medicine than a revised model criminal code will be needed to cure the more serious diseases afflicting criminal legislation today-such as undue legislative focus on harm relative to culpability, and overly harsh punishment for drug crimes, repeat offenders, and minor participants. (Donald Dripps' proposed supermajority and sunset requirements for criminal legislation ${ }^{87}$ are the type of therapy needed here.)

But a revised Code could address some of the problems. Consider the widespread use of strict liability. One response is to reiterate, in emphatic terms, the MPC's opposition to this form of criminal liability. Another, perhaps more realistic, response would be to permit quasi-strict liability but always allow a

85 See Stuart P. Green, Prototype Theory and the Classification of Offenses in a Revised Model Penal Code: A General Approach to the Special Part, 4 BufF. CRIM. L. Rev. 301 (2000); see also Ronald Gainer, The Culpability Provisions of the Model Penal Code, 19 RUTGERs L.J. 575, 589-91 (1988).

${ }^{86}$ For some preliminary thoughts on this question, see Kenneth W. Simons, When is Strict Criminal Liability Just?, 87 J. CRIM. L. \& CRIMINOLOGY 1075, 1093-95 (1997) and Simons, supra note 51 , at 393-97.

87 Donald A. Dripps, The Liberal Critique of the Harm Principle, 17 CRIM. JUST. ETHICS 3 (1998). 
reasonableness defense ${ }^{88}$ or to permit strict liability in grading but not in criminalization, ${ }^{89}$ or to insist that the actor must at least be aware of facts that would put him on notice of the dangerousness of his conduct and of the possible precautions he could take.

Moreover, another aspect of strict liability deserves reconsideration. The increasing criminalization of conduct formerly governed only by private law and civil regulation has made it increasingly unfair to expect all persons to be aware of the criminal law, at their peril. A few courts have responded by rejecting strict criminal liability for mistake of law in at least some categories of cases. ${ }^{90}$ So it is time to seriously consider providing a more general excuse to all defendants who are faultlessly ignorant or mistaken with respect to the criminal law. (New Jersey has taken this step; ${ }^{91}$ I am not aware of evidence that the change has been problematic.)

The MPC's mens rea provisions are a dramatic improvement over prior law. The definitions are much clearer, and the "element analysis" concept is immensely powerful and illuminating. But the mens rea provisions might also be viewed as victims of their own success. Progress is not perfection, and I sense that the MPC's enormous advance initially had the effect of stultifying new thought by American $^{92}$ courts and academics about this critical dimension of substantive criminal law. Moreover, courts have encountered difficulty with numerous concepts including mistake of law, recklessness, willful blindness, and extreme

88 See Laurie Levenson, Good Faith Defenses: Reshaping Strict Liability Crimes, 78 CORNELL L. REV. 401 (1993) (endorsing a general affirmative defense of good faith or non-negligence).

89 Under this approach, strict liability would be permitted as to an element that distinguishes degrees of a crime (e.g. quantity of drugs possessed or property stolen), but not as to an element that differentiates whether the conduct is criminal or noncriminal (e.g. whether the actor has violated a regulatory offense). See Simons, supra note 86, at 1095-1105.

90 Many federal statutes are now interpreted as requiring some degree of knowledge of illegality. See generally Sharon L. Davies, The Jurisprudence of Willfulness: An Evolving Theory of Excusable Ignorance, 48 DUKE L.J. 341 (1998); John S. Wiley, Not Guilty by Reason of Blamelessness: Culpability in Federal Criminal Interpretation, 85 VA. L. REV. 1021 (1999).

91 N.J. STAT. ANN. \& $2 \mathrm{C}: 2-4(\mathrm{c})(3)$ provides a defense upon clear and convincing proof that the actor has "diligently pursued all means available to ascertain the meaning and application of the law of the offense to his conduct and honestly and in good faith concludes his conduct is not an offense in circumstances in which a law-abiding and prudent person would also so conclude." One of the two reported cases discussing this provision does construe it somewhat narrowly. See State v. Guice, 621 A.2d 553, 558 (N.J. Super. Ct. Law Div. 1993) (suggesting that the defense is difficult to establish if the defendant has not consulted a lawyer); see also New Jersey v. Pelleteri, 683 A.2d 555 (N.J. Super. Ct. App. Div. 1996) (finding that very clear statutory language precludes the defense).

92 Outside of the United States, however, mens rea has been a more vital topic of inquiry. The British literature, in particular, is full of thoughtful analysis of mens rea criteria, including indifference. 
indifference. More recently, however, a number of commentators have offered interesting and promising suggestions for reform. As I have tried to show in this essay, their suggestions and other revisionist proposals deserve serious attention. 
